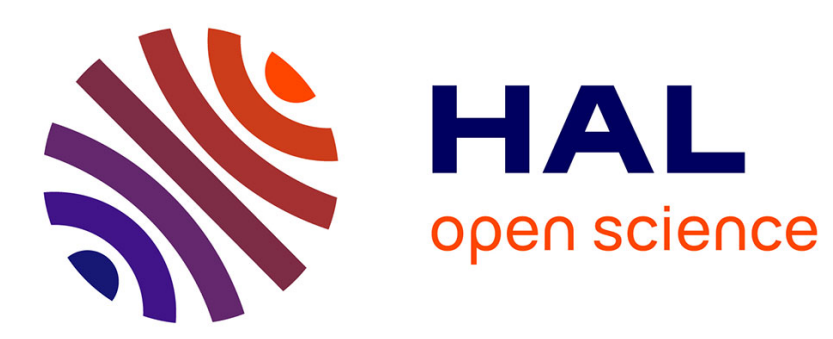

\title{
X-UV multilayered optics and related technics
}

\author{
P. Dhez
}

\section{To cite this version:}

P. Dhez. X-UV multilayered optics and related technics. Revue de Physique Appliquée, 1988, 23 (10), pp.1578-1578. 10.1051/rphysap:0198800230100157800 . jpa-00245988

\section{HAL Id: jpa-00245988 https://hal.science/jpa-00245988}

Submitted on 1 Jan 1988

HAL is a multi-disciplinary open access archive for the deposit and dissemination of scientific research documents, whether they are published or not. The documents may come from teaching and research institutions in France or abroad, or from public or private research centers.
L'archive ouverte pluridisciplinaire HAL, est destinée au dépôt et à la diffusion de documents scientifiques de niveau recherche, publiés ou non, émanant des établissements d'enseignement et de recherche français ou étrangers, des laboratoires publics ou privés. 


\section{X-UV multilayered optics and related technics}

\section{Introduction}

The first layered synthetic mirrors for X-rays were prepared around 1954 but their real use date only from 1982. The decisive progress was due to E. Spiller who effectively demonstrated the possibilities to overcome the grazing incidence constraints by the use of such interferential mirrors optimized to X-UV. More recently Bragg-Fresnel optics have been developed by combining the properties of grating and those of Bragg diffraction (V. V. Aristov et al.). The articles selected for this special issue try to review the present state of the art in interferential X-UV optics and their uses in : astrophysics (R. C. Catura et al.), laser fusion experiments (R. Benattar et al.) or for pulsed high flux X-ray sources (L. Knight et al.).

The first article in this issue (J. M. André and B. Pardo) is an introduction to the general problem of the interaction between stratified media and an electromagnetic wave. Due to the specific values of the X-UV optical constants this well studied problem in visible and radar waves needs special treatment. Concerning X-UV reflectivity optimization, one needs to look about the more convenient evaporation methods for a large diversity of couple of metals (A. Rosenbluth) and to take care about interface diffusion between ultrathin layers of these materials (C. Piecuch). To improve the interface qualities and the periodicity of layering, one way is to perform in-situ X-ray reflectivity measurements during evaporation (J.P. Chauvineau) or ellipsometry in visible ( $\mathrm{P}$. Houdy). The X-ray reflectivity tests a posteriori are generally performed at the wavelength in use. This allows one to take into account the different types of imperfections which are difficult to model in theoretical studies (R. Barchewitz et al., F. Christensen, L. Nevot, E. Spiller).

The efficiency of such interferential optics are directly connected to the ability to obtain ultrathin periodic layers with individual thickness around one nanometer. Some technological difficulties encountered here are similar to those known in very large scale integration (VLSI) and optoelectronics. Layered synthetic media at the nanometer scale for X-UV optics is presently a subject of research in several countries. For example, in Japan such research is included in the « Nano Project Program »; an article gives a report about $\mathrm{X}$-UV layered optics research and projects in this country (T. Namioka).

From a more general point of view, the study of surface defects, the artificially layered material with very small periods and the interface problems are questions arising more and more frequently in several fields of physics, chemistry and biology. Another goal of this issue is to show why, in its own way, the making and testing of interferential X-UV optics can bring deeper insight to the knowledge about the surfaces and interfaces. 